\title{
Two Pathways for Formation of D-Amino Acid Conjugates in Pea Seedlings*
}

\author{
Yoshiko Kawasaki, Tadashi Ogawa and Kei Sasaoka \\ Department of Nutrition, School of Medicine, The University of Tokushima, \\ Kuramoto-cho, Tokushima 770, Japan
}

Received July 28, 1980

\begin{abstract}
D-Alanıne and several D,L-amıno acids were adminıstered to pea seedlings to investigate formation of D-amino acid conjugates. The $N$-malonylation was found to occur with all the Damino acıds administered. D-Alanıne was specifically converted to additional $\gamma$-L-glutamyl conjugate, and this $\gamma$-L-glutamylation predominated over the $N$-malonylation with respect to D-alanine. The other D-amino acids tested were slightly or scarcely utılized for $\gamma$-L-glutamylation The overall results indicate that two systems exist for formation of D-amino acid conjugates in pea seedlings: (a) $N$-malonylation of common D-amıno acids and (b) $\gamma$-L-glutamylation highly specific to D-alanine.
\end{abstract}

Recent development of sensitive methods for the optical resolution of amino acid enantiomers $^{1,2)}$ has allowed accumulation of evidence for the natural occurrence of D-amino acids in higher plants. Previously, ${ }^{3,4)}$ we demonstrated that large amounts of D-alanine occurred in pea seedlings, which existed mainly in conjugated forms, that is, $\gamma$-L-glutamyl- and $N$-malonyl-D-alanine. Both conjugates were formed in an early stage of germination. ${ }^{5)}$ During the course of studies on the metabolism of D-alanine in pea seedlings, we showed that D-alanine was synthesized from Lalanine by a racemase reaction ${ }^{6}$ and also demonstrated that several D-amino acids occurring in the seedlings were synthesized by $\mathrm{D}$ alanine aminotransferase (EC 2.6.1.21). ${ }^{7 \sim 9)}$

In this work, ${ }^{14} \mathrm{C}$-D-alanine and several ${ }^{14} \mathrm{C}$ D,L-amino acids were administered to pea seedlings to study the metabolic pathways of D-amino acids. Attention was focused on the formation of D-amino acid conjugates in the seedlings.

\section{MATERIALS AND METHODS}

Materials. D-[U- $\left.{ }^{14} \mathrm{C}\right]$ Alanine $(40 \mathrm{mCl} / \mathrm{mmol})$ was pur-

* This work was supported by a Grant-in-Aid for Scientıfic Research from the Minıstry of Education, Science and Culture of Japan chased from the Radiochemical Centre (Amersham, England). D,L- $\left[1-{ }^{14} \mathrm{C}\right]$ Leucine $(51.6 \mathrm{mCi} / \mathrm{mmol})$ was obtained from New England Nuclear Co. (Boston, Ma, U.S.A ). D,L- $\left[4-{ }^{14} \mathrm{C}\right]$ Valine $(39 \mathrm{mCl} / \mathrm{mmol})$ and $\mathrm{D}, \mathrm{L}-[3-$ $\left.{ }^{14} \mathrm{C}\right]-\alpha$-amino- $n$-butyric acid $(26.8 \mathrm{mC} / \mathrm{mmol})$ were products of the Commissariat a L'Energie Atomique (Saclay, France) The distribution of the label was confirmed to be equivalent in both $\mathrm{D}$ - and $\mathrm{L}$-1somers of the latter three ${ }^{14} \mathrm{C}$ $\mathrm{D}, \mathrm{L}$-amino acids by the method of chromatographic resolution described below. D-Amino acid oxidase (EC 1.4.3 3) and lactate dehydrogenase (EC 1.1.1.27) were purchased from Sigma Chemical Co. (St. Louis, Mo, U.S.A.). $\gamma$-L-Glutamyl-D-alanıne was synthesized as described previously ${ }^{4)}$ The other $\gamma$-L-glutamyl peptides were prepared from phthalyl-L-glutamic anhydride and the Damino acids (D- $\alpha$-amino- $n$-butyric acid, D-valine and Dleucine),${ }^{10)}$ and were used as marker for the detection of the radioactive $\gamma$-L-glutamyl peptides with the automatic amino acid analyzer as described below. All other reagents used were commercial products of analytical grade.

Pea seedlings and administration of labeled compounds. Pea seeds (Ptsum satıvum, L. cv. Alaska) sterilızed with $0.01 \%$ Osvan solution were germinated in the dark on moist filter paper at $25^{\circ} \mathrm{C}$ as described previously ${ }^{11)}$ At the 6-day stage of germination, both cotyledones and radicals were removed, and the remaining parts of the seedlings (shoots) were used for the experiment. Ten shoots were placed in a small beaker containıng $2 \mathrm{ml}$ of a ${ }^{14} \mathrm{C}$-amıno acid solution $\left(10^{-3} \mathrm{M}, 5 \mu \mathrm{C} 1\right.$ with respect to the $\mathrm{D}$ enantiomer) and incubated in the dark at $25^{\circ} \mathrm{C}$ for $5 \mathrm{hr}$. Under these conditions, above $90 \%$ of the ${ }^{14} \mathrm{C}$-amino acids tested was absorbed by the shoots within $5 \mathrm{hr}$.

Fractionation of D-amino actd conjugates The shoots to 
which ${ }^{14} \mathrm{C}$-amino acids had been administered were homogenized with $75 \%$ ethanol solution at $4{ }^{\circ} \mathrm{C}$. The extract was applied to a $0.9 \times 5 \mathrm{~cm}$ column of Dowex $1 \times 4$ (100 200 mesh, acetate form). The column was washed with $40 \mathrm{ml}$ of water. The compounds adsorbed were eluted with $160 \mathrm{ml}$ of $0.05 \mathrm{M}$ acetic acid (F-I fraction), $40 \mathrm{ml}$ of $1 \mathrm{M}$ acetic acid (F-II fraction) and $20 \mathrm{ml}$ of $4 \mathrm{M}$ formic acid (F-III fraction), successively. $\gamma$-L-Glutamyl peptides and $N$-malonyl D-amino acids were recovered in the F-II and F-III fractions, respectively.

Determination of $\gamma$-L-glutamyl peptides. Prior to the analyses, authentic $\gamma$-L-glutamyl peptides were added as markers to the F-II fractions, except for that prepared from ${ }^{14} \mathrm{C}$-D-alanine-treated shoots. A one-third portion of the F-II fraction was applied to the amino acid analyzer, and $\gamma$-L-glutamyl peptides and radioactivity were determined after fractionation of the effuluent into $3 \mathrm{ml}$ fractions. The rest of the F-II fraction was hydrolyzed with $6 \mathrm{M}$ $\mathrm{HCl}$ at $100^{\circ} \mathrm{C}$ for $3 \mathrm{hr}$ and the hydrolyzate was used to determine the constituent amino acids and their optical configurations.

Determination of $N$-malonyl D-amino acids. Analyses of ninhydrin-negative $N$-malonyl D-amino acids in the F-III fractions were carried out as follows. The F-III fraction was evaporated to dryness in vacuo at $35^{\circ} \mathrm{C}$ and the radioactive compound was purified by preparative paper chromatography with $n$-butanol-acetic acid-water ( $4: 1: 1$, by vol.). The radioactive area was located by autoradiography as described previously ${ }^{3)}$ and the compound was quantitatively eluted with water. A one-half portion of the compound isolated was hydrolyzed with $6 \mathrm{M}$ $\mathrm{HCl}$ at $100^{\circ} \mathrm{C}$ for $3 \mathrm{hr}$. The hydrolyzate was used for the determination of the constituent amino acid and its optical configuration. The radioactivity of the amino acid was measured after separation with an amino acid analyzer. The rest of the compound was subjected to structural analysis by gas-liquid chromatography-mass spectrometry.

Analyses. Amino acid analysis was carried out with an automatic amino acid analyzer, Yanaco LC-5S, under the following conditions: Aminex A-4 resin, $0.9 \times 60 \mathrm{~cm}$ column; $0.2 \mathrm{~N}$ sodium citrate buffer, $\mathrm{pH} 3.25$ and 4.25 ; flow rate, $80 \mathrm{ml} / \mathrm{hr}$; column temperature, $52^{\circ} \mathrm{C}$.

The radioactivity was measured with an Aloka LCS-602 liquid scintillation spectrometer equipped with an external standardization system. ${ }^{12)}$

Identification of $\mathrm{N}$-malonyl $\mathrm{D}$-amino acids was performed using a gas-liquid chromatography-mass spectrometer, Varian MAT 312, equipped with a $0.16 \times$ $150 \mathrm{~cm}$ glass column of OV-101 $3 \%$ on Chromosorb W). The compounds isolated were converted to the methylesters with diazomethane and analyzed under the same conditions as described previously. ${ }^{3}$ )

The optical configurations of the amino acids obtained from the hydrolyzates of the conjugates were determined by the use of D-amino acid oxidase ${ }^{13)}$ or by chromatographic resolution of their diastereoisomeric L-leucyl dipeptides. $^{8,9,14)}$

\section{RESULTS}

\section{Formation of the $\gamma$-L-glutamyl peptides}

Figure 1 shows chromatographic separation of the radioactive compounds in the F-II fraction prepared from the shoots treated with ${ }^{14} \mathrm{C}$-D-alanine. Almost all the radioactivity in

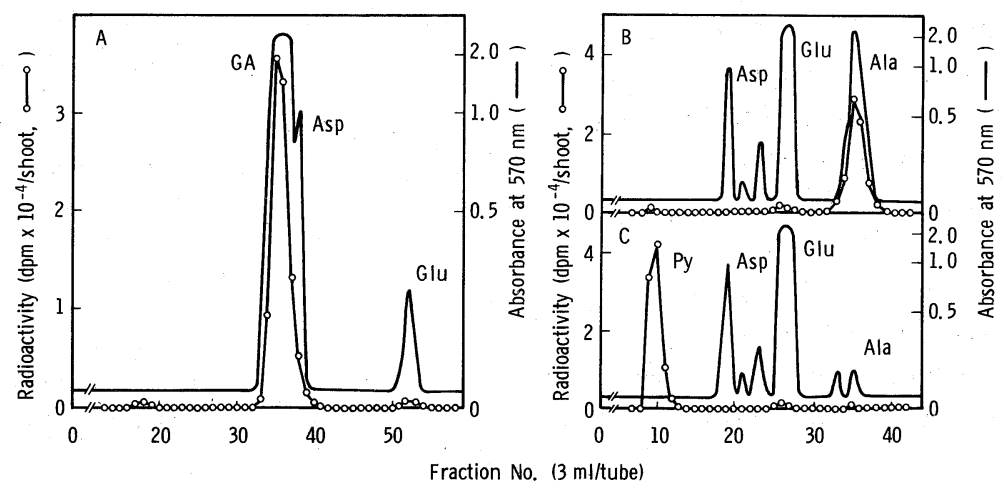

FIG. 1. Chromatographic Evidence for the Formation of Radioactive $\gamma$-L-Glutanyl-D-alanine.

A. Chromatogram of the F-II fraction obtained from the ${ }^{14} \mathrm{C}$-D-alanine-treated shoots. B. Chromatogram of the hydrolyzate of the F-II fraction. C. Chromatogram of the D-amino acid oxidase-treated hydrolyzate of the F-II fraction. The amounts of the samples used in analyses A, B and C each corresponded to one-third of the F-II fraction prepared from 10 shoots. The analytical conditions are described in MATERIALS AND METHODS except that a $0.9 \times 30 \mathrm{~cm}$ column was used for the analyses B and C. GA, $\gamma$-L-glutamyl-D-alanine; Py, pyruvic acid (determined by the lactate dehydrogenase system ${ }^{3)}$ ). 
Table I. Formation of $\gamma$-L-Glutamyl PePtides

The values in parentheses indicate the ratios relative to D-alanine. Experimental details are described in Materials AND Methods.

\begin{tabular}{|c|c|c|}
\hline \multirow{2}{*}{$\begin{array}{l}{ }^{14} \mathrm{C} \text {-Amino acid } \\
\text { administered }\end{array}$} & \multicolumn{2}{|c|}{$\gamma$-L-Glutamyl peptides* } \\
\hline & $\begin{array}{l}\text { D-Amino acid } \\
(\mathrm{dpm}\end{array}$ & $\begin{array}{l}\text {-Amino acid } \\
\text { hoot) }\end{array}$ \\
\hline D-Alanine & $9.8 \times 10^{4}(1)$ & - \\
\hline $\begin{array}{l}\mathrm{D}, \mathrm{L}-\alpha-\text { Amino- } n \text {-butyric } \\
\quad \text { acid }\end{array}$ & $2.0 \times 10^{4}(0.2)$ & $2.0 \times 10^{3}$ \\
\hline $\mathrm{D}, \mathrm{L}-$ Valine & $1.8 \times 10^{3}(0.02)$ & $1.4 \times 10^{4}$ \\
\hline $\mathrm{D}, \mathrm{L}-$ Leucine & $3.8 \times 10^{2}(0.004)$ & $4.2 \times 10^{3}$ \\
\hline
\end{tabular}

* Formed during incubation for $5 \mathrm{hr}$.

the F-II fraction was recovered in the ninhydrin-positive peak corresponding to $\gamma$-Lglutamyl-D-alanine. The hydrolyzate of this fraction gave glutamic acid and radioactive alanine, which was readily decomposed into radioactive pyruvic acid by $\mathrm{D}$-amino acid oxidase (Figs. 1B and C). Glutamic acid released had the L-configuration. These results indicate that the radioactive compound in the F-II fraction was $\gamma$-L-glutamyl-D-alanine. The formation of $\gamma$-L-glutamyl peptides from the amino acids administered is summarized in Table I. In the case of ${ }^{14} \mathrm{C}-\mathrm{D}, \mathrm{L}-\alpha$-amino- $n$ butyric acid-treated shoots, radioactivity was also found in the ninhydrin-positive peak corresponding to authentic $\gamma$-L-glutamyl-D- $\alpha$ amino- $n$-butyric acid added as a marker and all the radioactivity in the hydrolyzate of the fraction was recovered as $\alpha$-amino- $n$-butyric acid, but it was not completely oxidized by the treatment with D-amino acid oxidase. The ratio of radioactivity of $\mathrm{D}$ - $\alpha$-amino- $n$-butyric acid to the L-form was determined to be $1: 10$.

The formation of radioactive $\gamma$-L-glutamyl peptides of L-amino acids was also observed when the shoots were incubated with ${ }^{14} \mathrm{C}-\mathrm{D}, \mathrm{L}-$ valine and ${ }^{14} \mathrm{C}$-D, L-leucine. However, in both cases, only small amounts of the $\gamma$-L-glutamyl peptides of the D-amino acids were formed, as shown in Table I.

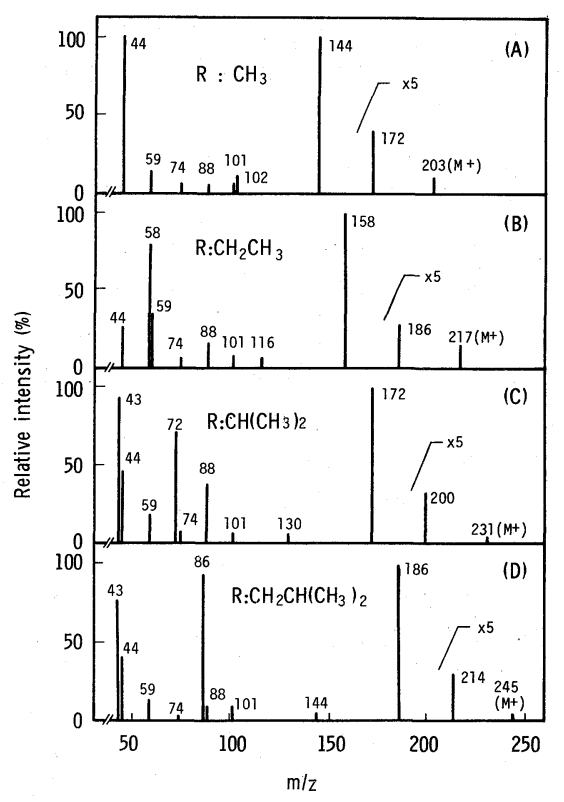

FIG. 2. Mass Spectra of the Ninhydrin-negative Conjugates Isolated from the Shoots Incubated with DAlanine (A), D,L- $\alpha$-Amino- $n$-butyric Acid (B), D,L-Valine (C), and D,L-Leucine (D), Respectively.

The general formula of the derivatives analyzed is as follows: $\mathrm{R}$ $\mathrm{CH}_{3}-\mathrm{O}-\mathrm{CO}-\mathrm{CH}_{2}-\mathrm{CO}-\mathrm{NH}-\mathrm{C} \mathrm{C}-\mathrm{CO}-\mathrm{O}-\mathrm{CH}_{3}$

TABLE II. Formation OF $N$-MALONYL D-AMINO ACIDS

Experimental details are described in MATERIALS AND Methods.

\begin{tabular}{lc}
\hline \multicolumn{1}{c}{$\begin{array}{c}{ }^{14} \text { C-Amino acid } \\
\text { administered }\end{array}$} & $\begin{array}{c}N \text {-Malonyl D-amino acids* } \\
(\mathrm{dpm} / \text { shoot })\end{array}$ \\
\hline D-Alanine & $2.9 \times 10^{3}$ \\
D,L- $\alpha$-Amino- $n$-butyric acid & $9.0 \times 10^{3}$ \\
D,L-Valine & $3.3 \times 10^{3}$ \\
D,L-Leucine & $2.1 \times 10^{3}$ \\
\hline
\end{tabular}

* Formed during incubation for $5 \mathrm{hr}$.

\section{Formation of $\mathrm{N}$-malonyl D-amino acids}

Figure 2 represents the mass spectra of the ninhydrin-negative conjugates isolated from the F-III fraction by preparative paper chromatography. All the conjugates gave distinct molecular ions $\left(\mathrm{M}^{+}\right)$and characteristic fragment ions assigned to $\left[\mathrm{M}^{+}-\mathrm{CH}_{3} \mathrm{O}\right]$, $\left[\mathrm{M}^{+}-\mathrm{CH}_{3} \mathrm{OCO}\right]$ (base peak), $\left[\mathrm{M}^{+}-\right.$ $\left.\mathrm{CH}_{3} \mathrm{OCOCH}_{2} \mathrm{CO}\right],\left[\mathrm{CH}_{3} \mathrm{OCOCH}_{2} \mathrm{CO}\right]^{+}(\mathrm{m} / z$, 
101) and $\left[\mathrm{R}-\mathrm{CH}=\mathrm{NH}_{2}\right]^{+}$(amine fragment). All radioactive amino acids in the conjugates were proved to have the D-configuration. From the results, the radioactive compounds found in the F-III fractions were identified as $N$-malonyl-D-alanine, $\quad-\mathrm{D}-\alpha$-amino- $n$-butyric acid, -D-valine and -D-leucine, respectively. Among these conjugates, $N$-malonyl-D- $\alpha$ amino- $n$-butyric acid was the first compound identified in plant materials, and the natural occurrence of $\mathrm{D}-\alpha$-amino- $n$-butyric acid was reported previously. ${ }^{8)}$ The formation of $N$ malonyl D-amino acids is summarized in Table II. No significant difference in the formation of these $N$-malonyl D-amino acids was observed.

\section{DISCUSSION}

In general, D-amino acids in higher plants exist in the conjugated form rather than in the free form, such as $N$-malonyl D-amino acids $^{3,15,16)}$ and various $D$-alanine containing peptides. ${ }^{17 \sim 19)}$ Several investigations on the metabolism of D-amino acids administered exogenously showed that the $N$-malonylation of D-amino acids commonly occurs in higher plants. $^{20 \sim 22)}$

Our previous studies ${ }^{3,5,6)}$ have shown that, in spite of the active accumulation of D-alanine conjugates in the germinating pea, free $D$ alanine in the tissue is kept at low levels $(0.02$ $\mu \mathrm{mol} / \mathrm{shoot}$ ) and that the incorporation of ${ }^{14} \mathrm{C}$ $\mathrm{D}$-alanine into the conjugates occurs rapidly and to an appreciable extent. Efforts to find free D-isomers of amino acids used in this experiment other than $\mathrm{D}$-alanine have been unsuccessful in the pea. In addition, it has also been demonstrated that the conjugates of Damino acids administered are the main metabolic products and that, compared with them, other transformations caused by possible reactions involving a racemase or an aminotransferase may be disregarded in the short period of the incubation $(3 \sim 5 \mathrm{hr}){ }^{1}{ }^{1}$ Therefore, in accord with these observations, the results shown in Tables I and II may provide additional evidence that the D-amino acids tested equally undergo $N$-malonylation whereas D- alanine is specifically converted to the $\gamma-\mathrm{L}$ glutamyl peptide. Except for $\mathrm{D}-\alpha$-amino- $n$ butyric acid, the $\gamma$-L-glutamylation of which is about $20 \%$ of that of D-alanine, the other Damino acids tested are scarcely utilized for the formation of $\gamma$-L-glutamyl peptides. The rate of $\gamma$-L-glutamylation seems to depend on the chain length of the D-amino acids. With respect to D-alanine, the difference between the observed rate of $\gamma$-L-glutamylation and that of $N$-malonylation in vivo is sufficient to account for the difference in the amounts of $\gamma-\mathrm{L}$ glutamyl- and $N$-malonyl-D-alanine found in intact seedlings.

The overall results presented here indicate the occurrence of two systems of D-amino acid conjugate formation in pea seedlings, that is, the $N$-malonylation of common D-amino acids and the $\gamma$-L-glutamylation highly specific and active for D-alanine. The latter system newly demonstrated here seems to be characteristic of the pea.

\section{REFERENCES}

1) T. Ogawa, Nippon Nôgeikagaku Kaishi, 54, R83 (1978).

2) T. Robinson, Life Sci., 19, 1097 (1976).

3) T. Ogawa, M. Fukuda and K. Sasaoka, Biochim. Biophys. Acta, 297, 60 (1973).

4) M. Fukuda, T. Ogawa and K. Sasaoka, Biochim. Biophys. Acta, 304, 363 (1973).

5) M. Fukuda, A. Tokumura, T. Ogawa and K. Sasaoka, Phytochemistry, 12, 2593 (1973).

6) T. Ogawa, Y. Kawasaki and K. Sasaoka, Phytochemistry, 17, 1275 (1978).

7) T. Ogawa, M. Fukuda and K. Sasaoka, Biochem. Biophys. Res. Commun., 52, 998 (1973).

8) T. Ogawa, N. Bando and K. Sasaoka, Agric. Biol. Chem., 40, 1661 (1976).

9) T. Ogawa, M. Kimoto and K. Sasaoka, Agric. Biol. Chem., 41, 1811 (1977).

10) J. P. Greenstein and M. Winitz, "Chemistry of the Amino Acids," Vol. 3, Wiley, New York, 1961, p. 1693.

11) K. Sasaoka, Mem. Res. Inst. Food Sci. Kyoto Univ., 14, 42 (1958).

12) H. Tsuji, K. Moritoki, T. Ogawa and K. Sasaoka, Agric. Biol. Chem., 41, 1413 (1977).

13) G. G. Guilbault, "Handbook of Enzymatic Methods of Analysis," Marcel Dekker, Inc., New York, 1976.

14) J. M. Manning and S. Moore, J. Biol. Chem., 243 
5591 (1968).

15) M. H. Zenk and H. Scherf, Biochim. Biophys. Acta, 71, 737 (1957)

16) N. Rosa and A. C. Neish, Can. J. Biochem., 46, 797 (1968).

17) M. Yamauchi, T. Ohashi and K. Ohira, Plant and Cell Phsiol., 20, 671 (1979).

18) M. Noma, M. Noguchi and E. Tamaki, Agric. Biol. Chem., 37, 2439 (1973).
19) J. L. Fahn and R. J. Illman, Phytochemistry, 14, 1464 (1975).

20) R. W. Aldag and J. L. Young, Agronomy J., 62, 184 (1970).

21) M. Pokorny, E. Marčenko and D. Keglević, Phytochemistry, 9, 2175 (1970).

22) B. Ladešić, M. Pokorny and D. Keglević, Phytochemistry, 10, 3085 (1971). 